\title{
Av. $x^{v}$ aranah-
}

\author{
Еігсні Імото \\ Professor, Osaka University of Foreign Studies
}

Yašt 19 is dedicated to the zam yazat, the earth god, and accordingly it is called the Zam (yād) Yašt. It is divided into two parts: there are enumerated mountains in Yt. 19.1-8 and from Yt. 19.9 there begins partitioning of fragards with numbering continued from the previous number 8 . The former part is concerned with the earth out of which the mountains rise up while the latter part down to its close is only concerned with the $x^{v}$ aronah (OP farnah, Pers. farr). Says F. Wolff, it begins von hier an in der Tat $X^{v}$ arr Yašt.(1) Yašt 18, a short Aštāt Yašt, treats of the farnah together with Aši, Tištrya and Vāta, nothing being referred to the earth itself.

However, according to Sïh Rōčak 1.28 and 2.28 the 28th day of every month is consecrated to the earth, and Mt. Uši. darana and two kinds of farnahs are there also praised as in Yt. 19.0. Even if the formation of the Sïh Rōčak were after the compilation of the Yašt 19 it is possible to say that the earth itself was originally praised on the 28th day of month together with mountains and the farnahs. If vice versa, the text of Yt. 19 might be so transmuted that they put much stress on legends of both axvarta and Kavian farnahs. So the Zam Yašt must claim a right to be more genuine than the Kayān Yašt in the oldest MS.(2) or the $\mathrm{X}^{\mathrm{v}}$ arr Yašt.

Besides the 28th day the 9th and 25th days are the days on which Ātar, the son of Ahura Mazda, often identified with Apąm Napāt, and Aši, the daughter of Ahura Mazda, are respectively praised with the two kinds of farnahs, Aryan and Kavian.

Aši, lot, reward, goddess who distributes bhakti, goddess of wealth, of fertility, Mater Dolorosa (Yt. 17.57-59), the Mother-goddess incorporated in the Zoroastrian theology, was another form of Anahita. The dyad of Aši and $\bar{A} \operatorname{tar}$ (=Apąm Napāt)(3) corresponds to that of Aphrodite and Adonis, Cybele and Attis, and so on. In view of the analysis of the Zoroastrian month names it is indisputable that they are of an agricultural calendar and there must be 
Magna Mater(s) in Iran like Ashtarte in Canaan, Ishtar in Babylon, Ge, Gaia or Demeter in Greece and Ceres or Ops in Rome. Avestan Armati which is borrowed later in Armenian as (Spand) aramet 'Bacchus' is also annotated, according to Neryosang's translation of Y. 31.4, 32.2 and Y. 1.2, as prthivior prthivipatni- 'earth or earth-goddess' just like OIndic aramati- commented by Sāyana as prthivi- on RV VII 35.8 and 42.3.(4) There were probably as many names of earth-goddesses in Iran as each independent local worship of the goddess was observed.

The farnah is related to the earth: When the sun brings warmth yazatas will appear by hundreds and thousands, gather the farnah, bring it down with them and divide it on the Ahura-created earth to promote Aša's property and body (Yt. 6.1): Aməša Spəntas keep the farnah in the moon and divide it down on the Ahura-created earth (Yt. 7.3): The mountain as is situated between heavens and the earth is the place where the farnah reaches first from heavens. It is because one prays for the mountains, the farnah and the brilliant, tall, strong, well-grown-up, merciful, good Aši.

The most sacred fire of the Sassanians was atur farröbag, that is, the fire of the farnah as bhakti or the fire of the farnah's share. The fire and the two farnahs almost stand on an equality (Ny. 5.5). The fire is produced as a result of lightning with heavy rains and sent down to the earth. So the fire is a son of heavens just as the rain (water) is, which is called Apąm Napāt equivalent to Vedic Apām Napāt often confused with the water-born Agni. The fire, the farnah, Aši as bhakti and the earth are inter-related entities. In Yt. 19.45-51 Ātar and Aži Dahāka struggle to obtain the $x^{v}$ aronah- $a x^{v} r a t a$ - but the farnah flows to the sea Vouru. kaša, where Apąm Napāt wants to snatch it up at the bottom of the deep sea. For Ātar in heavens, to put it in another way, Apąm Napāt in the waters the farnah is indispensable thing to become an entire entity. Thus the farnah is inseparably related to the earth, Ātar and Aši.

The etymology of Av. $x^{v}$ aronah- has been sought in Persian $x^{v}$ ardan 'to eat' by H. W. Bailey who took the etymon $x^{v} a r$ - as 'to partake, take' and defined the meaning of $x^{v}$ aronah - as 'a thing obtained or desired', thence 'a good thing, a desirable thing, possessions, good things.' It was therefore a concrete expression concerned with this earthly world. ${ }^{(5)}$ No scholar seems to have ever proposed the etymon $x^{v}$ ar- 'to eat'.

Av. $x^{v}$ ara $\theta$ - 'thing eaten, food, Speise', $x^{v}$ arati- 'eating, Essen' are both derived from $x^{v} a r$ - 'to eat' and they stand at the end of compound words: 
$x^{v} a r \partial \theta a-$

$\operatorname{anax}^{v} \operatorname{ar} \partial \theta-$

hāmo. $x^{v}$ arəoa-

paitinam. $x^{v}$ ar $\partial \theta$ -

aiwiš. $x^{v}$ arəAa-, anaiwiš. $x^{v} a r \partial \theta a-$

duš. $x^{v}$ arəoa-

mainyuš. $x^{v} r \partial \theta a-$

pasuš. $x^{v}$ arəta-

$x^{v}$ arati-

haoma. $x^{v}$ aroti-

haomō. anuharati-

franuharoti-.

Besides $x^{v}$ ar $\theta a$ - there is $x^{v}$ arana- 'Essen, Trinken, Air Wb. 1869' as the last member of the compound:

avō. $x^{v}$ arana-

paitis. $x^{v}$ arona-

ayanhō. paitišx $x^{v}$ arona-

hamuharana-

đ̊suharana-.

Av. $x^{v}$ arrnah $^{3}$ means 'Nahrung' in N. 30 (Air Wb. 1873).

Av. $x^{v}$ aronah $^{-1}$ which has been interpreted as 'glory, splendor, fortune, etc.' can stand also at the end of compounds:

ušta. $x^{v}$ aronah-

vispō. $x^{v}$ aranah-

barō. $x^{v}$ aranah-

vindi. $x^{v}$ aronah-

-ənə $(\mathrm{NSg} \mathrm{m})$

aiwi. $x^{v}$ aronah-

pouru. $x^{v}$ aronah-

aš. $x^{v}$ aronah-

duš. $x^{v}$ aronah-.

In Avestan there are some words which end with -nah-comparatively more productive than those in Old Indic:

raēxənah- 'Erbe'<raēk- 'linquere', OInd. reknas-

afnah- 'Habe'<ap- 'erreichen', OInd. apnas-

tafnah- 'Hitze'<tap- 'heiss sein'

rafnah-, rafonah- 'Stütz'<rap- 'Unterstützung gewähren' 
Oamnah- 'Sorge', cf. OInd. çam-

varanah- 'Farbe'<var- 'hüllend bedecken', OInd. varna-

varošnah- 'Tun'<varəz- 'wirken'.

They are all neuter nouns.

According to A. Meillet and E. Benveniste the IE suffix *-nes had a notion of social character like Lat. pignus, facinus, funus, fenus as well as munus. Further, Meillet underlined that the Old Indic formation with -nas, that of-*nes of Lat. munus and a small number of words as well is concerned with the forms of 'property' such as dravinas- 'property, cf. Av. draonah-', apnas- 'possession', reknas'inherited possession'.(6) According to Meillet's suggestion Av. $x^{v}$ aranah- would be applicable to the above-mentioned view, much more if one accepts Bailey's interpretation as 'possession, riches, fortune'.

However, the meaning of the farnah is not only 'glory, riches, fortune' but also 'a kind of magical power': many Avestan passages which contain the farnah show that the farnah does not always mean 'kingly glory' or 'fortune, riches' but sometimes means a kind of magical power to promote or stimulate the functions of nature and human beings. The farnah stands in a line with ama- 'Angriffskraft', aojah- 'Kraft', varəəra- 'Wehr-Angriffskraft' and zāvar- '(physische) Kraft, Starke' in Yt. 1.22: the farnah is a magical power. In Yt. 14.2 the farnah occurs with baêsaza- 'Heilmittel' and ama-.

By virtue of the rayi and the farnah of fravašis the waters flow forth by the unexhausted spring, the plants grow up out of the ground by the spring and the wind flying into the clouds blows by the spring (Yt. 13. 14). By their virtue women conceive children, have an easy delivery when they become pregnant (Yt. 13. 15). By their rayi and farnah will be born an eloquent man whose word is listened to in the assemblies... by their rayi and farnah the sun will go on his path, the moon goes on her path and go the stars on their path (Yt. 13. 16). But could one be convinced that by virtue of fravašis'(7) 'riches, splendor or fortune' the functions of nature and human beings be promoted or stimulated?

The farnah and the rayi often make a dyad. It sounds very likely that both the words have the meanings of almost the same class. 'Riches, possession' sounds plausible for both the words; it is probable that $x^{v}$ arrnah- and rayi- are based on $x^{v} a r$ - 'to take' and $r \bar{a}$ - 'to give'. But it is hardly fit for many passages.

Av. $r \bar{a}$ - means like OInd. $r \bar{a}$ - to make an offering to the god or to bestow something to human beings (from the god's side) while Av. $d \bar{a}$ - means like OInd. 
$d \bar{a}$ - to give in general or to give something to human beings (from the god's side). So OInd. dāna- and dhana- have different conception from rayi- which, originally more ritual, is an 'offering' from the man's side and a 'heavenly gift' from the god's side. Av. draonah-is a portion of the offering which is the godsend in turn at the communion with the deity. Men and the god would sit together and eat the sacramental food in common. Pahl. drōn 'sacramental bread at the ritual' keeps the tradition. OInd. dravinas- lost the meaning long ago and got the meaning of 'social character'. The sacramental food and drink consisted of Av. myazda- and zaotrā-, OInd. miyedha- and soma-. Besides these the Avesta kept fast to the draonah. OInd dravinas- became one's 'financial ability, wealth, res' according to which one could make an offering to the god.

Av. draonah- in Y. 11.7 gãuš... haomāi draonō 'a portion of the ox for Haoma' is such a gift that one can get the divine power by eating though in Pahlavi tradition it is replaced by bread instead of meat. In the Rig Veda Soma is called dravinodā-, dravinodas- or dravinovid-. It will be inferred from the Avestan passage that OInd. dravinas- too had relation to Soma in the earliest stage. Thence, Av. *draonahvant- (OInd. dronasvant-), raēvant- (OInd. revant-) and $x^{v}$ aronahvant- are consisted of draonah-, rayi- and $x^{v}$ aranah-, the former two of which are offerings to be eaten to share the divine power. The farnah was sure to be eaten in the traditional Mazdayasnian ceremonies including the accession of the king to the throne, which idea was inherited from the cult of the Mother-goddess. Av. rayi- and OInd. rayi- were in the oldest stage as such. Ahura Mazda is raêvantand $x^{v}$ aronahvant-. Is he just rich and wealthy? Allāh is rahìm and raḥmān; $\mathrm{He}$ is merciful. Ahura Mazda should be benevolent and $\mathrm{x}^{\mathrm{v} a r \partial n a h v a n t-.}$ Tištrya also has both the modifiers while men have, on the contrary, ordinarily only one of them (Vd. 20. 1, Yt. 14, 27, Vyt. 1). Av. $x^{v}$ aranahvant- is placed side by side with Indo-Iran. * raivant-. It is Iranian first of all. Av. $x^{v}$ aronahvantmust have almost the same meaning as raēvant-, so $x^{v}$ aranah- and rayi- have almost the same conception.

When a portion of the offering was eaten in common with the god the eater became a recipient of divine qualities. The rayi was originally something to eat for the sake of the sacramental communion with the deity as it was the god himself and the divine power itself. Raêvant-is the quality of the god who bestows the divine power upon mankind and at the same time the quality of mankind who through offering gets the divine power from the god by eating in common with him. 
The Aramaic ideogram of Pahl. $x^{v}$ arrah is GDH. It is natural to suppose that the Aramaic word should be equivalent to Old Iranian $x^{v}$ aronah- or farnaheven in the Achaemenian age. The farnah was so everyday word that one could translate it into Aramaic which it seems was so usual as well.

Aram. $G D$ or $G D^{\prime}$ have several meanings: 1. coriander, grain, 2. fortune, luck, fortune as the god, Gad, genius Tyche.(8) Although Gad is a male god, Tyche of the Greeks is represented as a goddess with a cornucopia and a rudder in her hands and a ring on her crown. She is the city-goddess, protectoress of the land; just as Smyrna, Salamis, Paphos and various Phoenician cities had Cybele, Aphrodite and Astarte so some Greek cities had Tyche as city-gods. ${ }^{(9)}$ Gad Yavan near Yerusalem is probably the name of a pool connected with the Siloah, perhaps the Fount of Virgin. (10) Greek Gad is a water-goddess too. A rudder in her hand is, it seems, connected with the waters. She is a goddess of fertility and the waters. 'Coriander and grain' is to 'Fortuna' what Osiris as the corn spirit is to Isis, or Apąm Napãt to Aši.

The ring on her crown resembles the one which, rather like a horseshoe, one sees on the relief of Ardashir's investiture at Naqš-e Rostam or the one which Ahura Mazda has in his hand on Achaemenian reliefs. A horseshoe with the points upward is to be seen on the door in Europe, Japan and other places. It is considered to be used against the evil eye.

The corn spirit seems to be symbolized as a winged disk or a ring with (sometimes) a human figure, which covers from Egypt to Iran,(11) even to Japan. Here, a disk or a ring is likely to represent a 'corn, grain, coriander'. And the winged disk is sometines the very bird with open wings. The legend of Yt. 19. $34 \mathrm{ff}$. that the Yima's Kavian farnah flied away three times in the form of the bird Vārogan when he began to tell a lie suggests that the Kavian farnah takes the form of a bird. The farnah and the winged disk are the same thing in themselves. In Japan one decorates one's door, early in the New Year, with a 'winged disk' made of straw with a large orange on the spot of the disk which shape of the decoration is exactly the same as Unvala's illustration Fig. $12 \mathrm{~h}$, the winged disk of the Hittites. (12) People regard it as the emblem of one's ancestors or the corn spirit. Another informal New Year's decoration is a Jack of straw with a ring about $10 \mathrm{~cm}$ in diameter and two 'legs' about $30 \mathrm{~cm}$ in length without an orange. It is like a horseshoe-shaped ring with two ribbons on Ardashir's relief at Naqš-e Rostam.

The legend of Yt. 19. 56-64 that non-Aryan Fraprasyan the Turic wanted 
to get the $x^{v}$ aronah- axvarata- which belongs to the Aryan lands, present (zāta-) and future (azāta-) in the sea Vouru. Kaša, tried three times only to fail to obtain it shows that the $x^{v}$ aranah- $a x^{v}$ arata- is related to the earth and the Aryan farnah different from the Kavian one which flied away from Yima.

The Aryan farnah and the Kavian farnah make a dyad. As in the Gathic period Kavians were daēvic so the idea of the Kavian farnah was not current then. Gathic hapax $x^{v}$ aranå which is derived from *hu-arnäh may be a homonym of $x^{v}$ aranah-1.

For the Zoroastrians the possessors of the fresh magical power were legendary or historical strangers or enemies who brought it with them from the lands beyond: they were Kavians. When the vigor of the king, warriors and men were believed to become weak and dying, like vegetation for example, at the end of the year, they had to reinforce the dying vigor with the fresh one. They had to eat something in common with the god in order to get it. Strangers or enemies were believed to possess it.

The $x^{v}$ aranah- axvarata- belongs to Apąm Napāt: it is the male principle. The Aryan farnah belongs to Assi: it is the female principle. The male principle must be born and die. It is dynamic and mobile while the female principle is static and immobile. Both the principles make the perfect entity so far as the male principle is without defect. When the Kavian farnah becomes to wane it is renewed by the new Kavian farnah. The new farnah is the $x^{v}$ aranah$a x^{v}$ arata- itself. Av. $a x^{v}$ arata- means 'not yet eaten, fresh, pertaining to the first fruits or the firstlings'. The Iranians had the idea of the first fruits or the firstling: Cyrus wanted Croisus to be offered as a first fruits of the booties of the war (Herod. I. 86, cf. I. 90, 92; IV. 88). The Sassanian farnah of Kārnāmak was a kid or a lamb. Perhaps they were the first fruits of the age. It is as though on Lammas the first fruits of the harvest or freshly-baked loaves of bread are presented on the altars of churches with cups of consecrated wine. One would present the first fruits with zaoOrä on the altar and afterward would partake a portion of them symbolizing the eating in common with the god.

Av. $x^{v}$ aronah- is derived from $x^{v}$ ar- 'to eat'. From $x^{v}$ arona- 'food' $x^{v}$ aranahgot the conception of the higher level and got the meanig 'a magical power one obtains after eating the sacramental food, the corn spirit, the first fruits'. The Kavian farnah is of the male principle. It is $a x^{v}$ arota- when one is going to obtain it for the first time. 


\section{Notes}

(1) F. Wolff, Avesta, die heiligen Bücher der Parsen, Strassburg 1910, p. 286(10).

(2) C. Bartholomae, Altiranisches Wörterbuch, Strassburg 1904, Sp. 1872; K. F. Geldner, Grundriss der iranischen Philologie II, Strassburg 1904, p. 7.

(3) J. Darmesteter, Le Zend Avesta III, Paris, 1893, p. LXXXI; J. Markwart, Wehrot und Arang, Leiden 1938, pp. $127 \mathrm{f}$.

(4) AirWb., Sp. 337; H. Reichelt, Avesta Reader, Strassburg 1911, pp. $115 \mathrm{ff}$.

( 5 ) H. W. Bailey, Zoroastrian Problems in the Ninth-Century Books, Oxford 1943, p. 2; G. Ito, GATHICA XIII Av. axvarata- $x^{v}$ aranah-, in Orient, XI, Tokyo 1975, pp. 35-44, where besides the author's interpretation Bailey's new proposal and those of other scholars are to be found; W. Lentz, Yima and Khvarenah in the Avestan Gathas, in A Locust's Leg in honour of S. H. Taqizadeh, London 1962, pp. 131-134; E. Benveniste, “Old Iranian", in Current Trends in Linguistics Vol. 6, The Hague-Paris 1970, p. 19; J. Kellens, "L'avestique de 1962 à 1972, addenda et corrigenda" in Kratylos, Jahrgang XVIII, 1973, Heft 1, Wiesbaden, p. 5.

(6) E. Benveniste, Le vocabulaire des institutions indo-européennes, Paris 1969, pp. 96, 188 and 193.

(7) E. Imoto, "Avestan fravasi-" in Near Eastern Studies dedicated to H. I. H. Prince Takahito Mikasa on the occasion of his sixtieth birthday, Tokyo 1975 (in Japanese), pp. 41-47. Here the author identified Av. fravasi- with Proto-Germanic *ferwarthi 'forward' and defined its meaning as 'promoter, stimulator'.

( 8 ) G. H. Dalman, Aramäisches Handwörterbuch, Göttingen 1938; M. Jastrow, A Dictionary of the Talgumim, the Talmud Babli and Yerushalmi, and the Midrashic Literature, New York 1950.

(9) See CITY-GODS, in Encyclopaedia of Religion and Ethics 3, Edinburgh 1910, pp. 680-681.

(10) Jastrow, op. cit., p. 210.

(11) J. M. Unvala, "The winged disk and the winged human figure on ancient Persian monuments", in Papers on Indo-Iranian and other subjects in honour of J. J. Modi, Bombay 1930, pp. 488-513 with illustrations.

(12) Unvala, op. cit., pp. 508, 506, from G. Contenau, La Glyptique Syro-Hittite, Paris 1922, p. 306. 